\title{
Determination and Distribution of Groundwater Composition in Deep Aquifer of Satkhira Municipality, Bangladesh
}

\author{
Tusar Kumar Das, Kamona Rani, Ashik Md. Mamun, Masum Howlader, \\ Molla Rahman Shaibur*
}

Department of Environmental Science and Technology, Jashore University of Science and Technology, Jashore-7408, Bangladesh

Received: 31 August 2020

Accepted: 20 January 2021

\begin{abstract}
Satkhira Municipality is located in the extreme South-Western coastal region of Bangladesh. This area exhibits complex hydro-geochemical characteristics along with the increasing tendency of soil and water salinity which created a need of groundwater quality assurance. The objectives of the study were to identify the composition of groundwater followed by attempts to investigate spatial distribution pattern of groundwater quality. This was done to identify places with the availability of best quality of drinking water. This was achieved by combining the geographical information system, statistical analysis and diagrammatic presentation. A total of 100 deep tube well (450 to 600 feet) water samples were collected during monsoon and dry season in 2018 and were analyzed for hydro-geochemical parameters. The groundwater was neutral to alkaline $(\mathrm{pH} 7.01$ to 8.66$)$ in nature. Total dissolved solids ranged from 132.7 to $1436.0 \mathrm{mg} \mathrm{L}^{-1}$ which gradually increased from North to South direction. Sodium was the most dominant cation with mean value of $48.28( \pm 27.48) \mathrm{mg} \mathrm{L}^{-1}$ in monsoon and $105.35( \pm 66.73) \mathrm{mg} \mathrm{L}^{-1}$ in dry season. On the contrary, $\mathrm{Cl}^{-}$ion was the dominant anion with mean value of $546.99( \pm 34.07)$ in monsoon and $424.68( \pm 398.59) \mathrm{mg} \mathrm{L}^{-1}$ in dry season. The high loading $(>0.6)$ in principal component analysis indicated that the major ions originated from mineralization of rocks and soils, which was supported by Gibbs diagram. Silicate weathering supposed to be the responsible factor for releasing $\mathrm{Na}^{+}$ion, while $\mathrm{Ca}^{2+}$ and $\mathrm{Mg}^{2+}$ ion in groundwater came from both silicate and carbonate weathering. Three distinct types of groundwater facies e.g. the mixed $\mathrm{NaCaCl}, \mathrm{NaCaHCO}_{3}$ and $\mathrm{NaCl}$ were active along the study area, indicating that the underground cation exchange process. Our study will be helpful for the decision makers for planning a better operation and maintenance of groundwater resources.
\end{abstract}

Keywords: groundwater modeling, hydro-geochemistry, water- rock interaction, Satkhira municipality

*e-mail: shaibur75@just.edu.bd; shaibur75@yahoo.com 


\section{Introduction}

Water is the most important and fundamental essence of life on earth. About $71.0 \%$ of the Earth surface is covered with water, of which only $1.0 \%$ is available as fresh and potable water [1]. Due to global population explosion, the groundwater is becoming increasingly important for the drinking, ecosystem health and economic development. Generally, the groundwater is considered to be safe rather than surface water in terms of microbial contamination. Groundwater is fairly ubiquitous, but its conditions vary enormously and exploitation is often undertaken with a limited understanding of the hydrochemistry and without sufficient evaluation of the resource quality, especially in developing countries [2]. The situation is worse in Bangladesh especially in coastal zone, which covers an area of $47,201 \mathrm{Km}^{2}$ and accommodating about 36.8 million of people [3]. Due to climate change, the Southwestern part of Bangladesh is being experienced with various types of disasters. The hydro-geochemical characteristics of the Southwestern coastal belt of Bangladesh is very complex and is frequently subjected to cyclones, storm surges, floods, river bank erosion [4] and salinity intrusion [5-6]. These factors are gradually increasing the surface and groundwater salinity and lead to acute shortage of safe drinking water [7].

The coastal aquifer is flushed and recharged seasonally during the monsoon, bringing an abundance of fresh subsurface water. But the recharge is highly variable due to the presence of intermittent, thick deposits of clays [8] and the groundwater quality determines the environmental characteristics of the area. The main factors that affect the groundwater quality are lithofacies geographical conditions, geochemical process, groundwater recharge and runoff condition which is mainly influenced by land use patterns [9]. Moreover, anthropogenic activities like fertilizer leaching, sewage leaching, spillages and high water supply demand, etc. influence groundwater quality. The contamination in groundwater arises from longer duration due to low flow rate of water through aquifer system. The chemical nature of groundwater is very important for determining the suitability for drinking, domestic, agricultural and industrial uses [10].

In recent times many methodologies are adapted to investigate the quality of groundwater and related hydro-geochemical process. These are multivariate statistical analysis [11], geochemical modeling [12], redox indicator and structural equation modeling [13]. The statistical analysis do not necessarily establish cause and effect relationship, but collects the information in a compact format by removing data redundancy as the first step in the complete analysis and thus assist in generating hypothesis for the interpretation of various hydro-chemical processes [14].

Recently, some works have been done in the Southwestern coastal region of Bangladesh to identify the suitability groundwater for drinking [15] and irrigation purposes. But the information is very scarce and almost none regarding the water quality of the extreme Southwestern coastal District Sathkhira of Bangladesh. The Southwestern part is very important, because many natural resources are present there and many people are also living there especially in Satkhira Municipal area. Therefore, the water quality information and distribution of suitable water in deep aquifer of the Municipality needs to be investigated. The aims of the study were to investigate the status of groundwater quality and associated geochemical process. The next step was to investigate spatial distribution of groundwater to identify the best places with best quality of drinking water in the study area.

\section{Material and Methods}

\section{Study Area}

Satkhira Municipality is situated between $21^{\circ} 36^{\prime}-22^{\circ} 54^{\prime} \mathrm{N}$ Latitudes and $88^{\circ} 54^{\prime}-89^{\circ} 20^{\prime} \mathrm{E}$ Longitudes (Fig. 1) and it covers an area of $31.1 \mathrm{Km}^{2}$. This municipality is an important sub-urban area in Southwestern Bangladesh. The world's largest tidal mangrove forests the Sundarbans is located in the Southern part of Satkhira District. Majority of the area of this District is predominantly rural and the main income comes from aquaculture and agriculture [16]. In 1977, the Satkhira Municipality was declared as "A" class Municipality and it is very sincere in providing good municipal facilities to its dwellers [17]. Geo-morphologically the Southwestern coastal zone of Bangladesh was under the process of active

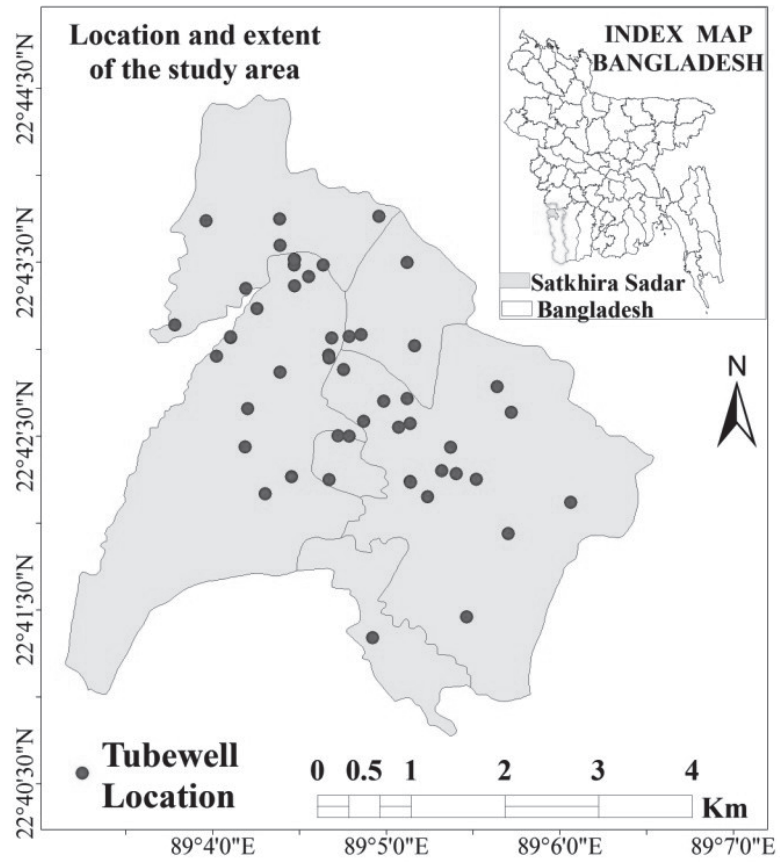

Fig. 1. Study area along with sampling locations. The samples were collected from July - December, 2018. 
delta formation by Ganges-Brahmaputra-Meghna river system. The major areas of this Ganges delta are frequently flooded with quaternary sediments eroded from high lands and deposited to those river tributaries [18]. The climate is of humid in nature and the average rainfall ranges from 1474 to $2265 \mathrm{~mm}$, while in dry months it varies from 20 to $65 \mathrm{~mm}$. The average temperature in the study area ranges from $296.15 \mathrm{~K}$ to $313.15 \mathrm{~K}$. The Ganges delta is extremely complex and dynamic because three distinct delta types exist are: tidal dominated, tide-river dominated and tide wave dominated [19]. The study area is characterized by three distinct aquifers. The first one is shallow aquifer overlain by a clay aquitard, while the second one is the first deep aquifer and the third aquifer is the deepest aquifer separated by deep aquitard from the upper deep aquifer [20].

\section{Sample Collection and Analysis}

A total of 100 deep tube-wells (DTW) (depth 450 to $600 \mathrm{ft}$ ) water samples were randomly collected from densely populated area of Satkhira Municipality during July to December, 2018. Two water samples were collected from same tube well in two different seasons (1) monsoon, when maximum rainfall occurs and (2) dry season, when minimum rainfall occurs. The samples were collected in $500 \mathrm{~mL}$ potable water bottles. At first, the bottles were washed with detergent and tap water and were socked in $0.1 \mathrm{~N} \mathrm{HNO}_{3}$ for 24 hours. Then the bottles were washed with tap water, rinsed with distilled water and finally were oven dried at $55^{\circ} \mathrm{C}$ for overnight. During sample collection, the bottle was prewashed and rinsed properly with sample water to avoid probable contamination. Firstly, tube wells were pumped exactly the number of times corresponding to the depth of the aquifer in feet (i.e. a 500 feet tube well was initially pumped for 500 times) and there after the water samples were collected. After collection, it was immediately brought to the Environmental Chemistry Laboratory of Jashore University of Science and Technology and analyzed. Sample temperature, $\mathrm{pH}$, electrical conductivity (EC) and total dissolve solids (TDS) were measured at the sampling points using Microprocessor $\mathrm{pH}$ meter (model- HANNA instrument $\mathrm{pH}$ 211) and conductivity meter (model- HI 8033). The measurement of $\mathrm{Na}^{+}$and $\mathrm{K}^{+}$were done by Flame Photometric Method (flame photometer- PEP7). The $\mathrm{TH}, \mathrm{Ca}^{2+}, \mathrm{Mg}^{2+}$ and $\mathrm{HCO}_{3}^{-}$were analyzed by titration colorimetric method and $\mathrm{Cl}^{-}$by titration ergonometric method. The $\mathrm{NO}_{3}^{-}, \mathrm{PO}_{4}^{-}$, and $\mathrm{SO}_{4}^{2-}$ were analyzed by Turbidimetric method with Spectrophotometer (modelUV-visible spectrophotometer, helios 949923045811) [21].

\section{Used Geochemical Modeling}

The Gibbs Diagram is widely used to establish the relationship between water composition and aquifer lithological characteristics [22]. Gibbs ratio I (for anion) $=\mathrm{Cl}^{-} /\left(\mathrm{Cl}^{-}+\mathrm{HCO}^{-}\right)$; Gibbs ratio II (for cation) $=\mathrm{Na}^{+} /\left(\mathrm{Na}^{+}+\mathrm{Ca}^{2+}\right)$, where all the ionic concentration were expressed in meq $\mathrm{L}^{-1}$. The Wilcox Diagram represents the suitability of water for irrigation and domestic purposes [23]. The spatial analysis tools of ArcGIS 10.5 were used to analyze the spatial variation of groundwater quality parameter in the study area. For interpolating point data in surface map inverse distance weighted algorithm was used [24].

\section{Statistical Analysis}

All statistical analysis was performed by using SPSS 20.0 and MS-Excel 2010. The factor analysis was applied to identify the chemical characteristics of water that were responsible for generating most of the variability within data set. The Principal Component Analysis (PCA) is ordinational statistical methods that essentially transform original data into a form that can be evaluated in multidimensional space [25]. Each factors in independent and varimax rotation was used to identify factors containing the greatest variability, the variability is represented as an eigenvalue [12]. The factors representing relatively large eigenvalue are highly important in describing the variability exhibited within the systems. The PCA is also a useful tool for providing idea about sub-surface geochemical process [26].

\section{Results and Discussion}

\section{Distribution of $\mathrm{pH}, \mathrm{EC}, \mathrm{TDS}$ and Salinity}

During monsoon, the $\mathrm{pH}$ values ranged from 7.01 to 8.66 , but in dry season the values were from 7.51 to 8.26 (Table 1). The $\mathrm{pH}$ values in all the samples were above $>7.0$, indicated that the water samples were slightly alkaline in nature. It seemed that the $\mathrm{pH}$ values of water samples were within the permissible value of Department of Environment (DoE) and World Health Organization (WHO) (Table 1). A study in Southwestern coastal Bangladesh also represented a similar range of $\mathrm{pH}$, which varies from 6.0 to 8.20. It was mentioned that, this was due to abrasion of abundant rock forming minerals like calcic plagioclase, micas, carbonates, clay and quartz [27].

The EC values varied a wide range, but the average was almost similar in both the seasons. In dry season, EC ranged from 304.10 to $2,347.0 \mu \mathrm{S} \mathrm{cm} \mathrm{cm}^{-1}$, while in monsoon the values ranged from 216.0 to $2,072.0 \mu \mathrm{S} \mathrm{cm} \mathrm{cm}^{-1}$ (Table 1). With few exceptions, most of the cases the EC values in Satkhira Municipality were within the permissible limit (Table 1). The kriging interpolation conducted by Naus et al. (2019) in Southwestern Bangladesh represent large scale regional trend in groundwater EC. It was found that EC value increased gradually from North to South in coastal 
Table 1. Descriptive statistics and the values compared with World Health Organization [48] and Department of Environment (DoE) [49] guideline for drinking water quality parameter.

\begin{tabular}{|c|c|c|c|c|c|c|c|}
\hline \multirow{2}{*}{ Variable } & \multirow{2}{*}{ Season } & \multirow{2}{*}{ Min. } & \multirow{2}{*}{ Max. } & \multirow{2}{*}{ Mean $( \pm \mathrm{SD})$} & \multicolumn{2}{|c|}{ Standards limits } & \multirow{2}{*}{$\begin{array}{c}\% \text { above WHO } \\
\text { limits }\end{array}$} \\
\hline & & & & & WHO & DoE & \\
\hline \multirow{2}{*}{$\mathrm{pH}$} & M & 7.01 & 8.66 & $7.79( \pm 0.41)$ & \multirow{2}{*}{$6.5-8.5$} & \multirow{2}{*}{$6.5-8.5$} & 2 \\
\hline & $\mathrm{D}$ & 7.51 & 8.26 & $7.82( \pm 0.17)$ & & & 0 \\
\hline \multirow{2}{*}{$\left.\mathrm{EC}(\mu \mathrm{S} \mathrm{cm})^{-1}\right)$} & M & 216.00 & 2072.00 & $829( \pm 485.84)$ & \multirow{2}{*}{-} & \multirow{2}{*}{$300-1500$} & 2 \\
\hline & $\mathrm{D}$ & 304.10 & 2347.00 & $731.7( \pm 434.4)$ & & & 1 \\
\hline \multirow{2}{*}{$\operatorname{TDS}\left(\mathrm{mg} \mathrm{L}^{-1}\right)$} & M & 132.70 & 1253.00 & $490.71( \pm 300.64)$ & \multirow{2}{*}{500} & \multirow{2}{*}{1000} & 4 \\
\hline & $\mathrm{D}$ & 187.50 & 1436.00 & $456.65( \pm 281.32)$ & & & 3 \\
\hline \multirow{2}{*}{ Salinity (ppt) } & $\mathrm{M}$ & 0.10 & 1.00 & $0.37( \pm 0.23)$ & \multirow{2}{*}{-} & \multirow{2}{*}{-} & 0 \\
\hline & $\mathrm{D}$ & 0.10 & 1.10 & $0.34( \pm 0.21)$ & & & 0 \\
\hline \multirow{2}{*}{$\mathrm{Na}^{+}\left(\mathrm{mg} \mathrm{L}^{-1}\right)$} & $\mathrm{M}$ & 8.27 & 130.69 & $48.28( \pm 27.48)$ & \multirow{2}{*}{200} & \multirow{2}{*}{200} & 0 \\
\hline & $\mathrm{D}$ & 15.22 & 283.71 & $105.35( \pm 66.73)$ & & & 5 \\
\hline \multirow{2}{*}{$\mathrm{K}^{+}\left(\mathrm{mg} \mathrm{L}^{-1}\right)$} & $\mathrm{M}$ & 0.01 & 4.93 & $0.46( \pm 0.92)$ & \multirow{2}{*}{30} & \multirow{2}{*}{12} & 0 \\
\hline & $\mathrm{D}$ & 2.12 & 26.77 & $7.06( \pm 5.25)$ & & & 0 \\
\hline \multirow{2}{*}{$\mathrm{Ca}^{2+}\left(\mathrm{mg} \mathrm{L}^{-1}\right)$} & $\mathrm{M}$ & 12.00 & 104.00 & $55.64( \pm 19.88)$ & \multirow{2}{*}{100} & \multirow{2}{*}{75} & 8 \\
\hline & $\mathrm{D}$ & 34.00 & 130.00 & $72.64( \pm 20.85)$ & & & 23 \\
\hline \multirow{2}{*}{$\mathrm{Mg}^{2+}\left(\mathrm{mg} \mathrm{L}^{-1}\right)$} & $\mathrm{M}$ & 6.00 & 42.00 & $24.31( \pm 8.93)$ & \multirow{2}{*}{150} & \multirow{2}{*}{$30-35$} & 6 \\
\hline & $\mathrm{D}$ & 9.60 & 78.00 & $25.12( \pm 10.91)$ & & & 6 \\
\hline $\mathrm{PO}^{3-}\left(\mathrm{m} \mathrm{II}^{-1}\right)$ & $\mathrm{M}$ & 0.73 & 11.92 & $2.33( \pm 2.92)$ & & 6 & 6 \\
\hline $\mathrm{OU}_{4}(\operatorname{Ing} \mathrm{L})$ & $\mathrm{D}$ & 0.01 & 5.38 & $1.04( \pm 1.25)$ & - & & 0 \\
\hline $\mathrm{SO}_{2}$ & $\mathrm{M}$ & 1.63 & 105.09 & $14.74( \pm 30.61)$ & 250 & 400 & 0 \\
\hline $\mathrm{SU}_{4}(\mathrm{Ing} \mathrm{L})$ & $\mathrm{D}$ & 0.01 & 3.53 & $0.64( \pm 0.81)$ & 250 & & 0 \\
\hline & M & 0.42 & 3.99 & $0.86( \pm 0.49)$ & 50 & 10 & 0 \\
\hline $\mathrm{NO}_{3}(\mathrm{III} \mathrm{L})$ & $\mathrm{D}$ & 0.42 & 3.92 & $0.83( \pm 0.48)$ & 50 & 10 & 0 \\
\hline $\mathrm{Cl}^{-}\left(\mathrm{m} \mathrm{II} \mathrm{I}^{-1}\right)$ & $\mathrm{M}$ & 70.90 & 1932.03 & $546.99( \pm 534.07)$ & 250 & $150-600$ & 18 \\
\hline Cl (ilig L) & $\mathrm{D}$ & 70.09 & 1834.53 & $424.68( \pm 398.59)$ & 250 & $150-000$ & 15 \\
\hline & M & 170.80 & 518.50 & $344.65( \pm 67.87)$ & 100 & & 0 \\
\hline $\mathrm{HCU}_{3}(\pi \mathrm{g} \mathrm{L})$ & $\mathrm{D}$ & 186.70 & 420.90 & $291.77( \pm 54.88)$ & 100 & - & 0 \\
\hline
\end{tabular}

N.B. DoE = Department of Environment, D = Dry Season, EC = Electrical Conductivity, M. = Monsoon, Max. = Maximum, Min. $=$ Minimum, $\mathrm{SD}=$ Standard Deviation, $\mathrm{TDS}=$ Total Dissolve Solid, $\mathrm{WHO}=$ World Health Organization

Bangladesh. Most of the groundwater in predominantly flashed Northern part is fresh and the Southern part is saline, as close to the Bay of Bengal [28]. The causes of increased salinity might also be rock mineralization and high evaporation (not possible in deep aquifer) due to increasing temperature in Satkhira region [4]. A report from China showed that about $42 \%$ samples were suitable $\left(\mathrm{EC}<500 \mu \mathrm{S} \mathrm{cm}^{-1}\right)$ for drinking while $50 \%$ were marginal (EC 500 to $1500 \mu \mathrm{S} \mathrm{cm}^{-1}$ ) and the rest $8 \%$ $\left(\mathrm{EC}>1500 \mu \mathrm{S} \mathrm{cm}^{-1}\right)$ were unfit for drinking purpose [29]. Generally, the deep tube wells of Jashore Municipality (depth 300 to $500 \mathrm{ft}$ ) contained low EC values [15]. The distance of Jashore Municipality is far from the
Bay of Bangle. But the present study area Satkhira is nearer to the Bay of Bengal and therefore, there was high possibility to have much higher concentration of soluble salts in Satkhira Municipality which was ultimately responsible for higher EC values for some samples.

In monsoon, the mean concentration of TDS was $490.71( \pm 300.64) \mathrm{mg} \mathrm{L}^{-1}$, but in dry season the value was $456.65( \pm 281.32) \mathrm{mg} \mathrm{L}^{-1}$ (Table 1). In the case of higher values, high TDS levels might be responsible for hardness of water which could affect the taste. In the present study, almost $55 \%$ of water samples exceeded the $\mathrm{WHO}$ and $8 \%$ exceeded the DoE drinking water 
quality standard (Table 1). The concentration of TDS gradually increased from West to Eastern part (Fig. 2). Another study of Southern Bangladesh reported that the TDS value ranged from 266.0 to $1770.0 \mathrm{mg} \mathrm{L}^{-1}$. The TDS level in the aquifer shows statistically significant variation at $1 \%$ significance level. This represents a spatial heterogeneous aquifer in the study area [27, 30].
The salinity of collected water samples showed a similar pattern of $\mathrm{pH}, \mathrm{EC}$ and TDS in both seasons and the values ranged from 0.10 to $1.10 \mathrm{ppt}$ (Table 1). A study from Assasuni Upazila of Satkhira District reported that about $25 \%$ groundwater comes from sea water sources. The groundwater salinity in first aquifer is mostly related with surface elevation. The water of
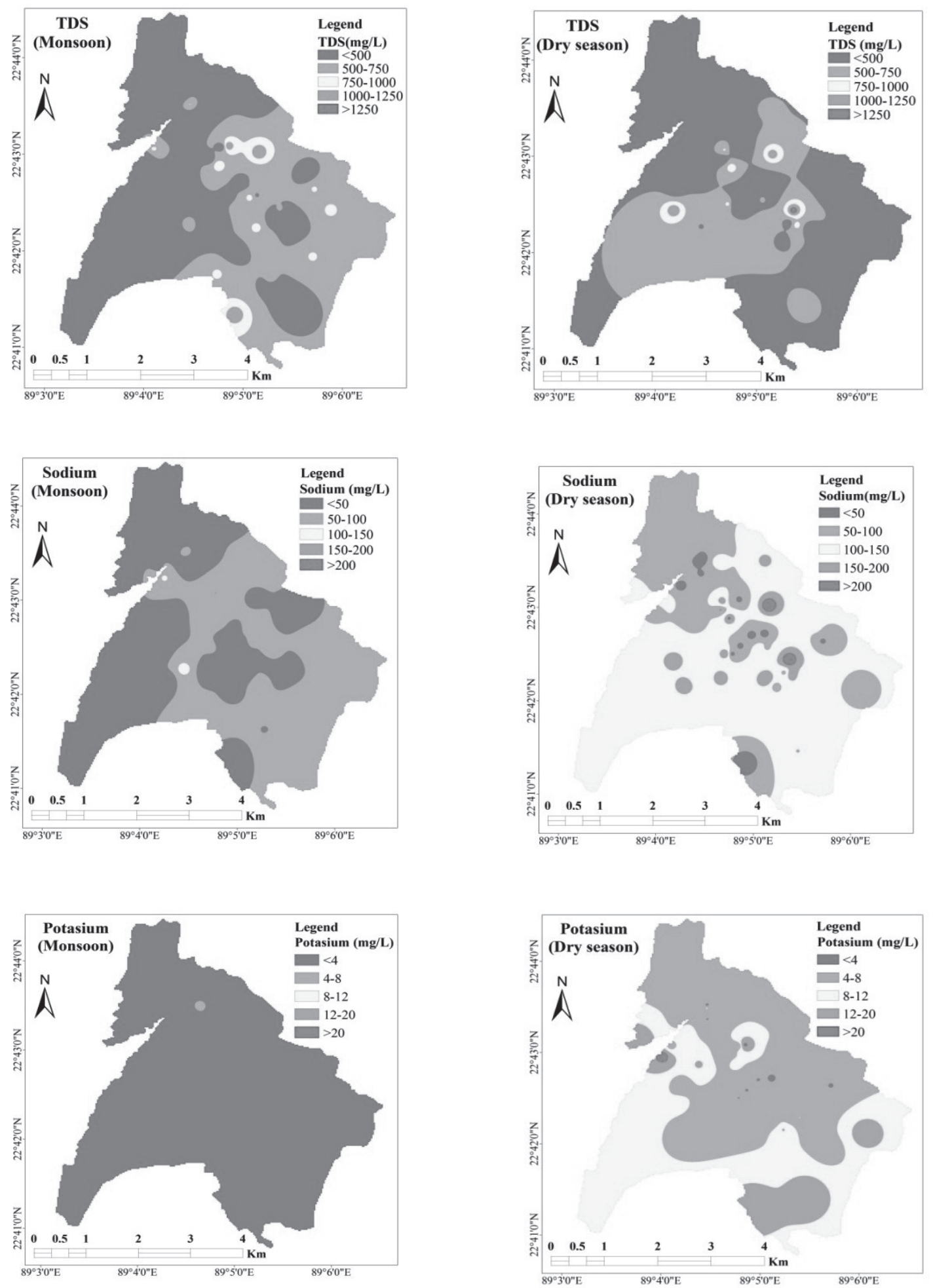

Fig. 2. Spatial distribution patterns of TDS, sodium and potassium in the study area. The samples were collected from July - December, 2018. 
higher elevated areas is relatively fresher than the lower elevated areas [26].

\section{Distribution of Major Cations}

Based on the concentrations of major cations, $\mathrm{Na}^{+}$ was the most dominating cation species. The values ranged from 8.27 to $130.69 \mathrm{mg} \mathrm{L}^{-1}$ in monsoon and 15.22 to $283.71 \mathrm{mg} \mathrm{L}^{-1}$ in dry season, followed by $\mathrm{Ca}^{2+}$, $\mathrm{Mg}^{2+}$ and $\mathrm{K}^{+}$(Table 1). Similar trend of anion, cation were also found in another study in Satkhira District [31] . The $\mathrm{Na}^{+}$is conservative in nature and it binds with clay minerals due to ion exchange [32]. The relatively high concentration of $\mathrm{Na}^{+}$was found in East-central part of Satkhira Municipality (Fig. 2). The weathering of rock forming minerals like sodium plagioclase, halite and the influence of domestic and animal wastes were mainly responsible for high concentration of $\mathrm{Na}^{+}$in groundwater. The ingestion of higher concentration of $\mathrm{Na}^{+}$may cause cardiac, renal and circulatory diseases to human beings [33]. In monsoon, the distribution of $\mathrm{K}^{+}$ was almost homogeneous in all parts of the study area, but in dry season high concentrations were found in central part (Fig. 2). The $\mathrm{K}^{+}$concentrations ranged from 2.12 to $26.77 \mathrm{mg} \mathrm{L}^{-1}$ (Table 1 ).

During monsoon the mean concentration of $\mathrm{Ca}^{2+}$ was $55.64( \pm 19.88) \mathrm{mg} \mathrm{L}^{-1}$ but in dry season it was relatively higher $72.64( \pm 20.85) \mathrm{mg} \mathrm{L}^{-1}$ (Table 1). A total of 8 samples in monsoon and 23 samples in dry season exceeded the WHO and DoE drinking water quality standard (Table 1). The $\mathrm{Ca}^{2+}$ concentration was relatively higher in Northern part as compared to other parts of the Municipality (Fig. 3). The $\mathrm{Ca}^{2+}$ concentration in the present underground water samples was relatively lower than the other reported data of coastal region of Bangladesh. This lover concentration of $\mathrm{Ca}^{2+}$ and sulfates may be due to the reaction of calcium and sulfates and subsequent precipitation [33].

The $\mathrm{Mg}^{2+}$ concentration in monsoon ranged from 6.00 to $42.00 \mathrm{mg} \mathrm{L}^{-1}$ and in dry season the values ranged from 9.60 to $78.0 \mathrm{mg} \mathrm{L}^{-1}$ (Table 1). The WHO recommended permissible limit value of $\mathrm{Mg}^{2+}$ concentration in drinking water is $150 \mathrm{mg} \mathrm{L}^{-1}$. About $12 \%$ of collected water samples crossed the permissible limit in both seasons. The higher concentration of $\mathrm{Mg}^{2+}$ was most probably due to the dissolution of $\mathrm{Mg}^{2+}$-bearing minerals in rocks. The other sources might be animal, domestic and or industrial wastes [34].

The concentrations of total $\mathrm{Ca}^{2+}$ and $\mathrm{Mg}^{2+}$ along with $\mathrm{HCO}_{3}^{-}$might be responsible for determination of total hardness in water. The high concentrations of $\mathrm{Ca}^{2+}$ and $\mathrm{Mg}^{2+}$ in groundwater were mostly responsible for increasing temporary hardness. The other cause was most probably due to leaching of those elements from soil, caused by flash irrigation or rainwater. The high standard deviation of some water quality parameters indicated the heterogeneous geochemistry in the study area.

\section{Distribution of Major Anions}

Among the anions, $\mathrm{Cl}^{-}$was the most dominating anion followed by $\mathrm{HCO}_{3}^{-}, \mathrm{SO}_{4}^{2-}, \mathrm{PO}_{4}^{3-}$ and $\mathrm{NO}_{3}^{-}$(Table 1). The $\mathrm{Cl}^{-}$concentrations ranged from 70.90 to 1932.03 mg $\mathrm{L}^{-1}$ in monsoon and 70.09 to $1834.53 \mathrm{mg} \mathrm{L}^{-1}$ in dry season (Table 1). About $40 \%$ of water samples exceeded the WHO drinking water quality standard. The relatively high concentration of $\mathrm{Cl}^{-}$was found in Southern part of the study area (Fig. 3), which is closed to the Bay of Bengal. The natural process like dissolution of salt deposits, weathering and sea water intrusion might be responsible for higher $\mathrm{Cl}^{-}$contents [35]. The higher concentrations of $\mathrm{Cl}^{-}$in the study area were also most probably due to influence of sea water intrusion or high evaporation rate [36].

During monsoon the mean concentration of $\mathrm{HCO}_{3}^{-}$was $344.65( \pm 67.87) \mathrm{mg} \mathrm{L}^{-1}$ but in dry season the value was $291.77( \pm 54.88) \mathrm{mg} \mathrm{L}^{-1}$ (Table 1). The high concentrations of $\mathrm{HCO}_{3}^{-}$ions in groundwater indicated the presence of carbonate minerals in aquifer. Weathering of carbonate and silicate minerals along with organic matter deposition from mangrove forest might contribute high concentrations of $\mathrm{HCO}_{3}^{-}$in groundwater [37]. The $\mathrm{Cl}^{-}$and $\mathrm{HCO}_{3}^{-}$showed a similar pattern of distribution along the study area (Fig. 3). It meant, the concentrations of $\mathrm{HCO}_{3}^{-}$increased gradually from Northern part to the Southern part (Fig. 3).

The concentration of $\mathrm{SO}_{4}^{2-}$ in monsoon ranged from 1.63 to $105.09 \mathrm{mg} \mathrm{L}^{-1}$, but in dry season the value was 0.01 to $3.55 \mathrm{mg} \mathrm{L}^{-1}$ (Table 1). The concentrations of $\mathrm{SO}_{4}^{2-}$ in groundwater might arise from dissolution of gypsum and anhydrite minerals. It might also be arisen from leaching, as the coastal soil of Bangladesh is $\mathrm{SO}_{4}^{2-}$ and $\mathrm{Cl}^{-}$dominated [38].

The monsoon and dry season showed different patterns of $\mathrm{PO}_{4}^{3-}$ distribution along the study area (data were not shown). In monsoon, the values ranged from 0.73 to $11.92 \mathrm{mg} \mathrm{L}^{-1}$ and the values were from 0.10 to $5.38 \mathrm{mg} \mathrm{L}^{-1}$ for dry season (Table 1). The high concentrations of $\mathrm{PO}_{4}^{3-}$ were found in the Northeastern part of the study area in both seasons (data were not shown).

The concentrations of $\mathrm{NO}_{3}^{-}$in the study area were very negligible and it showed similar patterns of distribution (Table 1), which gradually increased from Northern part to Southern part (data were not shown). During monsoon, the mean concentration of $\mathrm{NO}_{3}$ was $0.86( \pm 0.49) \mathrm{mg} \mathrm{L}^{-1}$, but in dry season it was 0.83 $( \pm 0.48) \mathrm{mg} \mathrm{L}^{-1}$ (Table 1). The low concentration of $\mathrm{NO}_{3}^{-}$in our samples indicated that the $\mathrm{NO}_{3}{ }^{-}$came from mineralization. Generally, the high $\mathrm{NO}_{3}^{-}$concentration in groundwater reflects that $\mathrm{NO}_{3}^{-}$comes from municipal waste, agricultural runoff and fertilizer leaching.

\section{Principal Component Analysis}

The PCA results of 13 water quality parameters of 100 deep tube well water samples were shown in Table 2. 

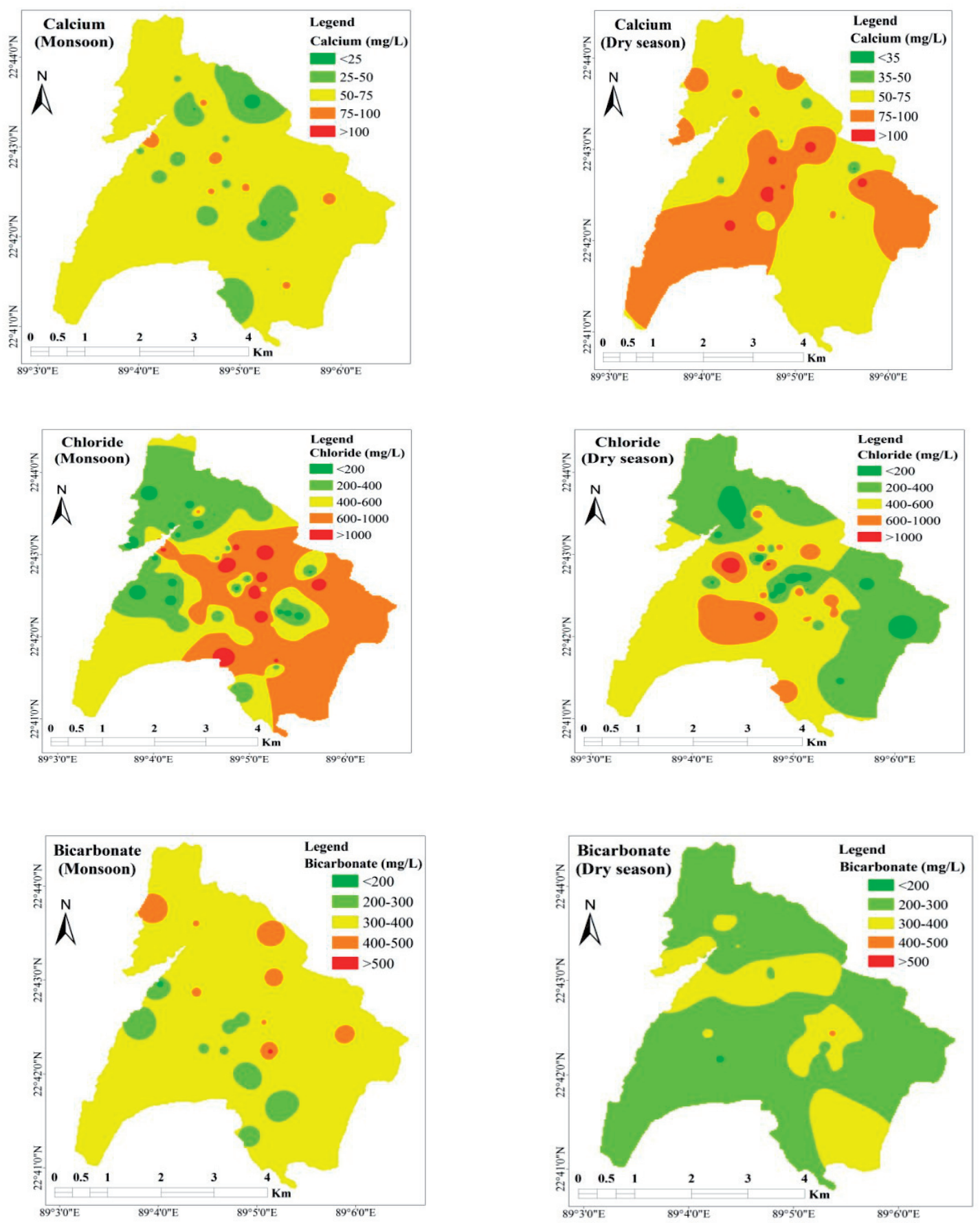

Fig. 3. Spatial distribution of calcium, chloride and bi-carbonate in deep tube well water samples collected from Satkhira Municipality. The samples were collected from July - December, 2018.

Four principal components (e.g. PC1, PC2, PC3 and PC4) have Eigenvalue $>1$ affecting the deep aquifer groundwater quality, which represented about $69.8 \%$ of variance in the data set. The PC1 represent $32.1 \%$ of variance, while the value was $49.1 \%$ for $\mathrm{PC} 2,61.1 \%$ for PC3 and $69.8 \%$ for PC4 (Table 2). For data interpretation the component loading factor $>0.6$ was considered [26].

The PC1 represented $32.1 \%$ of total variance. High positive loading value of EC, TDS, salinity, $\mathrm{Na}^{+}$and $\mathrm{Cl}^{-}$ were $0.956,0.964,0.948,0.709$ and 0.751 , respectively
(Table 2). A strong linear correlation between factor and parameter was found. The high concentration of EC and TDS were most probably due to higher dissolved minerals in water. The high loading of $\mathrm{Na}^{+}$ and $\mathrm{Cl}^{-}$indicated that the dissolution of evaporitic minerals. The significant loading of those ions in PC1 indicated a similar source of those ions. The soil water interaction and dissolution of $\mathrm{Na}^{+}$bearing minerals might be responsible for high $\mathrm{Na}^{+}$loading $[26,39]$. The PC2 accounted for $17 \%$ of total variance, which was positively correlated with $\mathrm{SO}_{4}{ }^{2-}$ and $\mathrm{HCO}_{3}{ }^{-}$ 
Table 2. Factors loading plot of different principal component with eigenvalue, $\%$ of variance and cumulative $\%$.

\begin{tabular}{|c|c|c|c|c|}
\hline Factor Loading & $\mathrm{F} 1$ & F2 & F3 & $\mathrm{F} 4$ \\
\hline $\mathrm{pH}$ & .123 & -.627 & -.501 & .066 \\
\hline $\mathrm{EC}$ & .956 & .152 & -.137 & .051 \\
\hline TDS & .964 & .136 & -.089 & .029 \\
\hline Salinity & .948 & .162 & -.118 & .039 \\
\hline $\mathrm{Na}$ & .709 & -.383 & .170 & -.236 \\
\hline K & .070 & -.348 & .601 & -.313 \\
\hline $\mathrm{Ca}$ & .328 & -.187 & .666 & .264 \\
\hline $\mathrm{Mg}$ & .015 & .459 & .637 & .143 \\
\hline $\mathrm{PO}_{4}$ & -.378 & .582 & -.076 & .040 \\
\hline $\mathrm{SO}_{4}$ & -.097 & .658 & -.100 & -.089 \\
\hline $\mathrm{NO}_{3}$ & -.082 & -.068 & -.005 & .906 \\
\hline $\mathrm{Cl}$ & .751 & .101 & -.025 & .145 \\
\hline $\mathrm{HCO}_{3}$ & .299 & .671 & -.066 & -.163 \\
\hline Eigenvalue & 4.183 & 2.211 & 1.551 & 1.130 \\
\hline$\%$ of Variance & 32.181 & 17.008 & 11.932 & 8.696 \\
\hline Cumulative \% & 32.181 & 49.189 & 61.120 & 69.816 \\
\hline
\end{tabular}

Extraction Method: Principal Component Analysis

a)

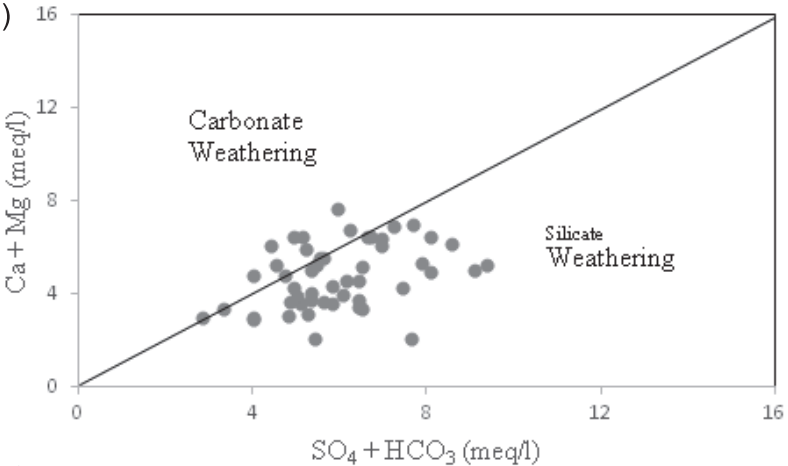

c)

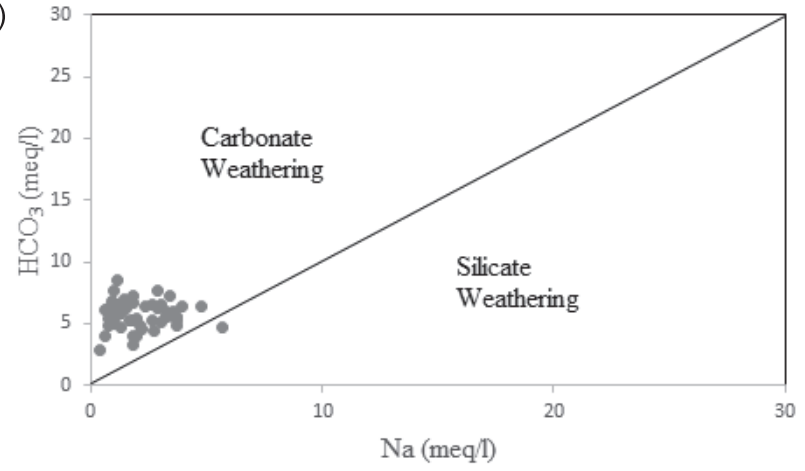

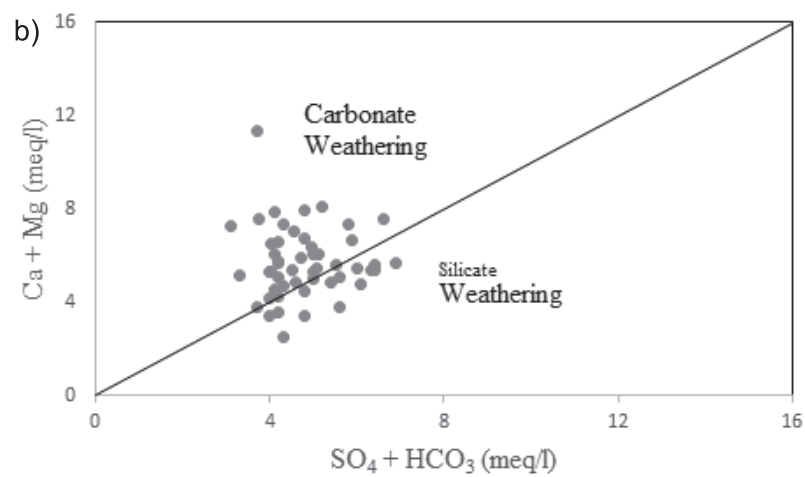

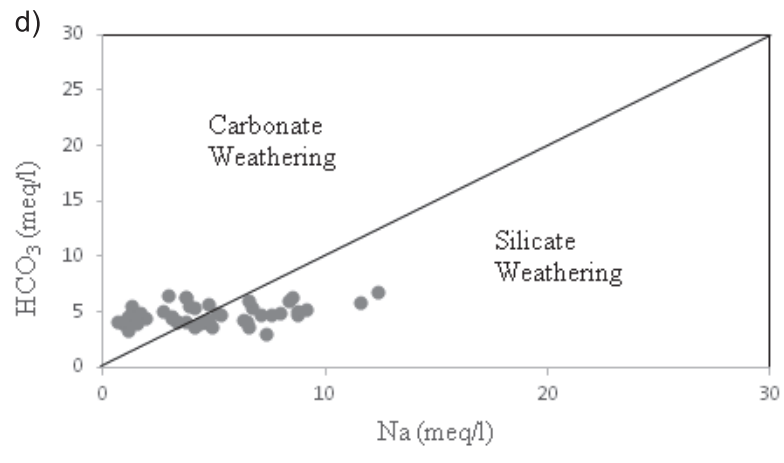

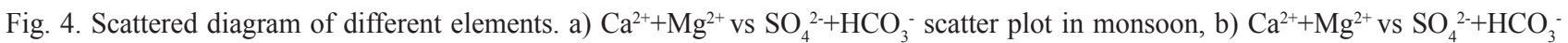
scatter plot in dry season, c) $\mathrm{HCO}_{3}^{-} \mathrm{vs} \mathrm{Na}^{+}$plot in monsoon and d) $\mathrm{HCO}_{3}^{-} \mathrm{vs} \mathrm{Na}^{+}$plot in dry season. The samples were collected from July - December, 2018. 
and strong negative correlated with $\mathrm{pH}$. The high loading factor of $\mathrm{SO}_{4}^{2-}$ and $\mathrm{HCO}_{3}^{-}$was most probably due to dissolution of $\mathrm{SO}_{4}^{2-}$ and $\mathrm{HCO}_{3}^{-}$bearing minerals and their mineralization decreased with increasing $\mathrm{pH}$ [40]. In PC3, high loading factors of $\mathrm{K}^{+}, \mathrm{Ca}^{2+}$ and $\mathrm{Mg}^{2+}$ were observed, which represented about $11.93 \%$ of total variance. Interestingly, high positive loading factor of $\mathrm{NO}_{3}^{-}$was observed in PC4 (Table 2). The anthropogenic activities like fertilizer application, organic matter deposition and seepage from septic tanks might be associated with high $\mathrm{NO}_{3}^{-}$concentration in the groundwater [41].

\section{Weathering and Dissolution}

The scatter plots between $\mathrm{Ca}^{2+}+\mathrm{Mg}^{2+}$ vs $\mathrm{SO}_{4}{ }^{2-}$ $+\mathrm{HCO}_{3}^{-}$and $\mathrm{HCO}_{3}^{-}$vs $\mathrm{Na}^{+}$were used to determine the impacts of weathering of carbonate or silicate minerals or evaporation dissolution on groundwater. Figs $4(a, b)$ showed that the weathering of carbonate and silicate minerals was equally responsible for determining groundwater quality. The $\mathrm{Ca}^{2+}$ and $\mathrm{Mg}^{2+}$ ions in groundwater were most probably originated from weathering of both carbonate and silicate minerals (Figs 4a, b). The scatter plot between $\mathrm{HCO}_{3}^{-} \mathrm{vs} \mathrm{Na}^{+}$ was used to explain ion exchange process. The sample
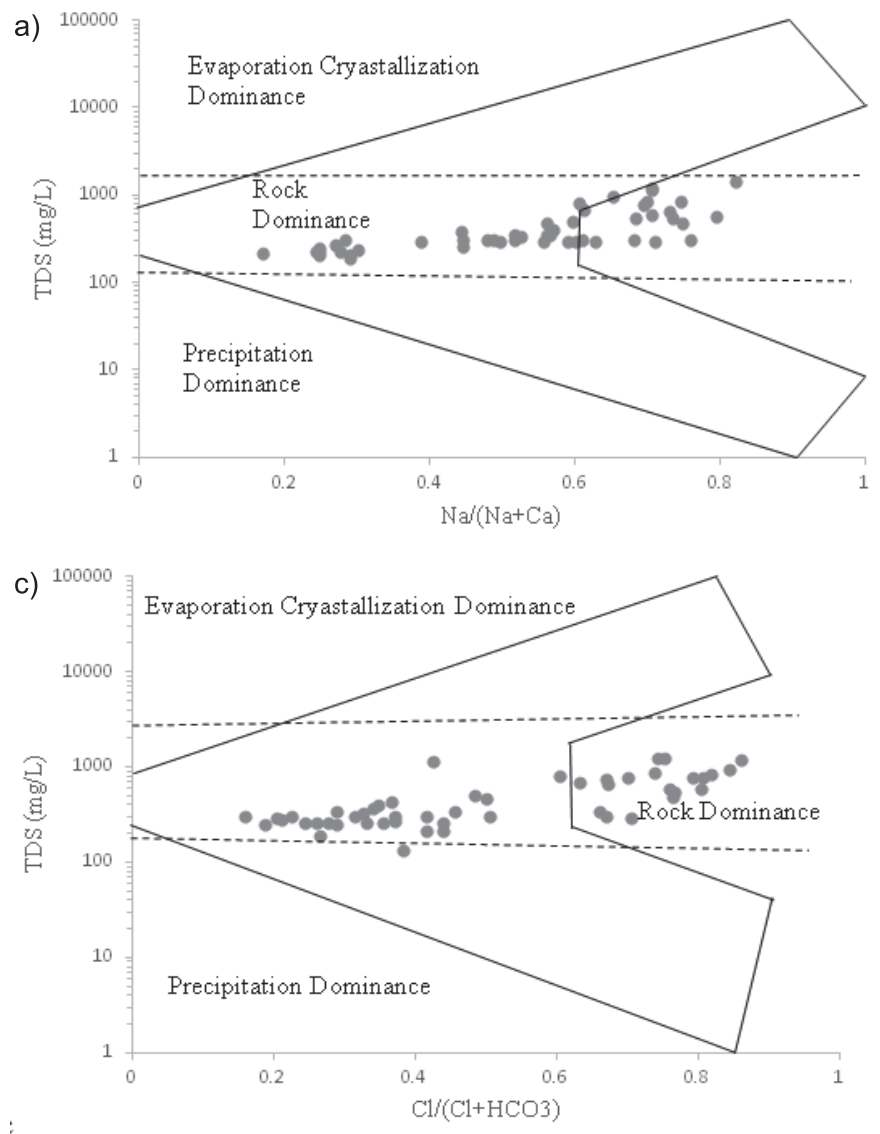

with 1:1 ratio indicated the dissolution of dolomite, gypsum or calcite. Our result showed that the $\mathrm{Na}^{+}$ion in groundwater originated from dissolution of carbonate minerals (Fig. 4). Dissolution of calcite, dolomite and gypsum in underground water was the dominated phenomenon. In our study, the relationships between $\left(\mathrm{Ca}^{2+}+\mathrm{Mg}^{2+}\right)$ and $\left(\mathrm{SO}_{4}{ }^{2-}+\mathrm{HCO}_{3}^{-}\right)$were very close to 1:1 $[42,43]$. The ion exchange known as direct tends to shift the points because of the excess $\left(\mathrm{SO}_{4}^{2-}+\mathrm{HCO}_{3}^{-}\right)$ over $\left(\mathrm{Ca}^{2+}+\mathrm{Mg}^{2+}\right)$. The reverse ion exchange shifted the points to the left. This was most probably due to increasing $\mathrm{Ca}^{2+}$ and/or $\mathrm{Mg}^{2+}$ released from rocks [43].

\section{Hydro-Chemical Facies}

Our results demonstrated that cations and anions in groundwater were mainly derived from rock weathering rather than evaporation, crystallization and precipitation (Fig. 5). More specifically, the majority of those ions were derived from weathering of $\mathrm{Ca}$ and $\mathrm{Mg}$ carbonate and crystalline dolomitic limestone. Both $\mathrm{Ca}^{2+}$ and $\mathrm{Mg}^{2+}$ may react with $\mathrm{HCO}_{3}^{-}$precipitating as calcite or dolomite. $\mathrm{As} \mathrm{Ca}^{2+}$ and $\mathrm{Mg}^{2+}$ react with $\mathrm{HCO}_{3}$, there would be straight positive correlation between $\mathrm{Ca}^{2+} / \mathrm{HCO}_{3}^{-}$and $\mathrm{Mg}^{2+} / \mathrm{HCO}_{3}^{-}$ratios [44]. The calcite and dolomite minerals precipitate when TDS value is more than $600.00 \mathrm{mg} \mathrm{L}^{-1}$. The TDS value in monsoon
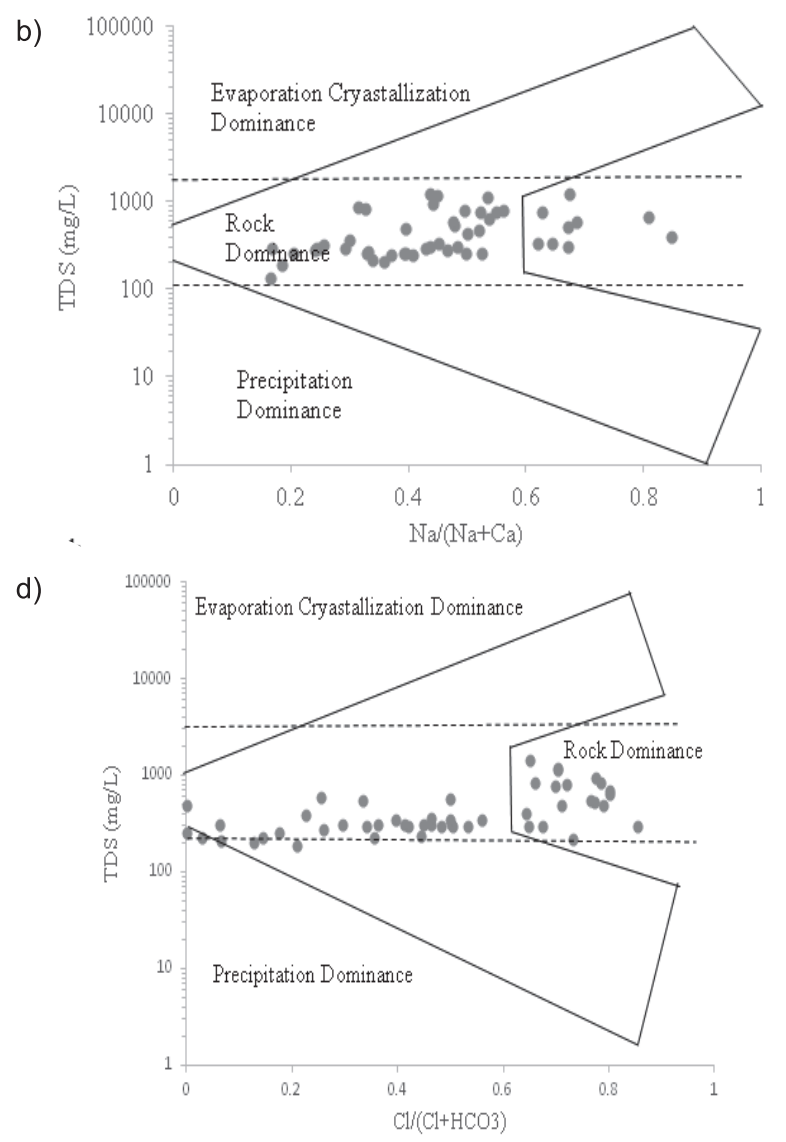

Fig. 5. Gibbs diagram for groundwater sample. a). TDS vs Na/(Na+Ca) in monsoon, b) TDS vs Na/(Na+Ca) in dry season, c). TDS vs Cl/ $\left(\mathrm{Cl}+\mathrm{HCO}_{3}\right)$ in monsoon, and d). TDS vs $\mathrm{Cl} /\left(\mathrm{Cl}+\mathrm{HCO}_{3}\right)$ in dry season. The samples were collected from July - December, 2018. 


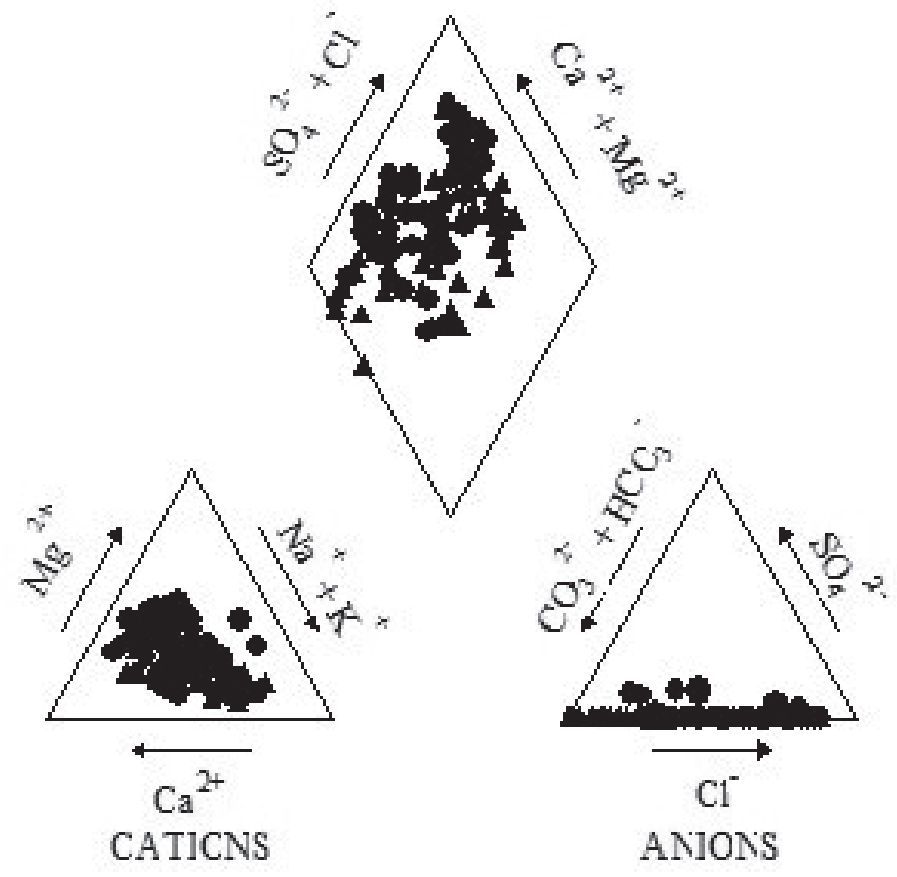

Fig. 6. Piper diagram. ( $\bullet$ = monsoon, $\boldsymbol{\Delta}=$ dry season). The samples were collected from July - December, 2018.

was $490.71 \mathrm{mg} \mathrm{L}^{-1}$ and in dry season the value was $456.65 \mathrm{mg} \mathrm{L}^{-1}$, which was lower than required value. Therefore, calcite and dolomite dissolution might not be occurred in the study area. If $\mathrm{Ca}^{2+}$ and $\mathrm{Mg}^{2+}$ ion originated from carbonate minerals then $\left(\mathrm{Ca}^{2+}+\mathrm{Mg}^{2+}\right) /$ $\mathrm{SO}_{4}^{2-}+\mathrm{HCO}_{3}^{-}$ration would be 0.5 [45] which was observed in Fig. 4. These ions in groundwater might be originated from weathering of carbonate minerals like pyroxene and amphibole (Fig. 4).

The chemical characteristics of aquifer system were mostly reflected in hydro-chemical facies, which was conceived by Hill and improved by Piper [46] and widely used for groundwater and surface water classification [47]. It is mainly represented bodies of groundwater in an aquifer that differ in their chemical composition. The facies are a function of the lithology, solution kinetics and flow patterns of the aquifer. Piper trilinear diagram indicated that cationic species $\mathrm{Na}^{+}$and $\mathrm{Ca}^{2+}$ and anionic species $\mathrm{Cl}^{-}$and $\mathrm{HCO}_{3}^{-}$were very much dominated in groundwater of Satkhira Municipality. Thus most of the water type in the study area consisted of $\mathrm{Na}^{+}$or $\mathrm{Ca}^{2+}-\mathrm{Cl}^{-} / \mathrm{HCO}_{3}^{-}$type (Fig. 6).

\section{Conclusions}

The mean trend of cations in the deep tube well water of Satkhira Municipality were $\mathrm{Na}^{+}>\mathrm{Ca}^{2+}>\mathrm{Mg}^{2+}>\mathrm{K}^{+}$ and majority of the water samples were dominated with $\mathrm{Na}^{+}$and $\mathrm{Ca}^{2+}$. While the trends of anions were $\mathrm{Cl}^{-}>\mathrm{HCO}_{3}>>\mathrm{SO}_{4}{ }^{2-}>\mathrm{PO}_{4}{ }^{3-}>\mathrm{NO}_{3}{ }^{-}$and most of the water samples were in $\mathrm{Cl}^{-}$and $\mathrm{HCO}_{3}^{-}$geochemical facies. The weathering of carbonate minerals mostly influenced the groundwater quality in the study area. The higher values of TDS and EC were found in Northern part while and $\mathrm{Cl}^{-}$and $\mathrm{HCO}_{3}{ }^{-}$were found in Southern part of the study area. Most of the water in the study area was $\mathrm{Ca}^{2+}$ or $\mathrm{Mg}^{2+}-\mathrm{Cl}^{-} / \mathrm{HCO}_{3}^{-}$dominated. Considering the all determined parameters the sampled water was recommended as suitable for drinking and certainly for irrigational use.

\section{Conflicts of Interest}

The authors declare no conflict of interest.

\section{References}

1. BHARTI R.K. Domestic Rainwater Harvesting- A Review. International Journal of Engineering Technology Science and Research. 3 (5), 193, 2016.

2. LUO X., JIAO J.J., MOORE W.S., CHERRY J.A., WANG Y., LIU K. Significant chemical fluxes from natural terrestrial groundwater rival anthropogenic and fluvial input in a large-river deltaic estuary. Water Research. 144, 603, 2018

3. MWR. Coastal Development Strategy', Water Resources Planning Organizations, Ministry of Water Resources, Government of People's Republic of Bangladesh. 2006.

4. SHAIBUR M.R., KHAN M.H., RASHID M.S. Climate change may cause natural disasters in Shyamnagar, Satkhira: The southwestern parts of Bangladesh. Bangladesh Journal of Environmental Science. 32, 101, 2017 .

5. SHAIBUR M.R., SHAMIM A.H.M., KHAN M.H., TANZIA F.K.S. Exploration of soil quality in agricultural 
perspective at Gabura and Buri Goalini Union: Shyamnagar, Satkhira, Bangladesh. Bangladesh Journal of Environmental Science. 32, 89, 2017b.

6. SHAIBUR M.R., SHAMIM A.H.M., KHAN M.H. Water quality of different sources at Buri Goalini and Gabura Unions of Shymnagar Upazila, Bangladesh. Environmental and Biological Research. 1 (2019), 32, 2019a.

7. DASGUPTA S., LAPLANTE B., MURRAY S., WHEELER D. Sea-level rise and storm surges: A comparative analysis of impacts in developing countries. The World Bank. 2009.

8. RAVENSCROFT P. An overview of the hydrogeology of Bangladesh. 2003.

9. RAJESH R., BRINDHA K., MURUGAN R., ELANGO L. Influence of hydrogeochemical processes on temporal changes in groundwater quality in a part of Nalgonda district, Andhra Pradesh, India. Environmental Earth Sciences. 65 (4), 1203, 2012.

10. KUMAR A., SINGH C.K. Characterization of hydrogeochemical processes and fluoride enrichment in groundwater of south-western Punjab. Water Quality, Exposure and Health. 7 (3), 373, 2015.

11. SINGH C.K., KUMAR A., SHASHTRI S., KUMAR A., KUMAR P., MALLICK J. Multivariate statistical analysis and geochemical modeling for geochemical assessment of groundwater of Delhi, India. Journal of Geochemical Exploration. 175, 59, 2017.

12. LEDESMA-RUIZ R., PASTÉN-ZAPATA E., PARRA R., HARTER T., MAHLKNECHT J. Investigation of the geochemical evolution of groundwater under agricultural land: a case study in northeastern Mexico. Journal of Hydrology 521, 410, 2015.

13. BELKHIRI L., NARANY T.S. Using multivariate statistical analysis, geostatistical techniques and structural equation modeling to identify spatial variability of groundwater quality. Water Resources Management. 29 (6), 2073, 2015.

14. GÜLER C., THYNE G.D., MCCRAY J.E., TURNER K.A. Evaluation of graphical and multivariate statistical methods for classification of water chemistry data. Hydrogeology Journal. 10 (4), 455, 2002.

15. SHAIBUR M.R., HOSSAIN M.S., SONY S.J. Drinking water quality of hand tube well water at sub-urban areas of Jashore Municipality, Bangladesh. Journal of Jessore University of Science and Technology. 4 (1), 11, 2019b.

16. AUERBACH L.W., GOODBRED JR S.L., MONDAL D.R., WILSON C.A., AHMED K.R., ROY K., STECKLER M.S., SMALL C., GILLIGAN J.M., Ackerly, B. A. Flood risk of natural and embanked landscapes on the GangesBrahmaputra tidal delta plain. Nature Climate Change. 5 (2), 153, 2015.

17. RAHMAN M.M., ISLAM M.S., ARGHA D.B.P., HAQUE M.M. Present scenario of municipal solid waste management in Satkhira Municipality. 4th International Conference on Civil Engineering for Sustainable Development. KUET, Khulna, Bangladesh (ISBN-978984-34-3502-6). 2018

18. GOODBRED (JR.) S.L., KUEHL S.A. The significance of large sediment supply, active tectonism, and eustasy on margin sequence development: Late Quaternary stratigraphy and evolution of the Ganges-Brahmaputra delta. Sedimentary Geology, 133 (3-4), 227, 2000.

19. ISLAM S.N., GNAUCK A. Mangrove wetland ecosystems in Ganges-Brahmaputra delta in Bangladesh. Frontiers of Earth Science in China. 2 (4), 439, 2008.
20. DPHE. Final report on development of deep aquifer database and preliminary deep aquifer map (first phage). Ministry of LGRD and Co-operative, Government of the People's Republic of Bangladesh. 14, Shaheed Captain Monsur Ali Sarani, Kakrail, Dhaka-1000, Bangladesh. 2006.

21. APHA. Standard methods for the examination of water and wastewater. APHA. AWWA and WPCF, $19^{\text {th }}$ Ed., Washington DC, USA. 1995.

22. GIBBS R.J. Mechanisms controlling world water chemistry. Science, 170 (3962), 1088, 1970.

23. WILCOX L. Classification and use of irrigation waters (No. 969). US Department of Agriculture. 1955.

24. SINGH C.K., RINA K., SINGH R.P., SHASHTRI S., KAMAL V., MUKHERJEE S. Geochemical modeling of high fluoride concentration in groundwater of Pokhran area of Rajasthan, India. Bulletin of Environmental Contamination and Toxicology. 86 (2), 152, 2011.

25. JOLLIFFE I.T. Principal component analysis. $2^{\text {nd }}$ edition, New York: Springer-Verlag, 2002. ISBN 0-387-95442-2. 2002.

26. SINGH C.K., KUMAR A., SHASHTRI S., KUMAR A., KUMAR P., MALLICK J. Multivariate statistical analysis and geochemical modeling for geochemical assessment of groundwater of Delhi, India. Journal of Geochemical Exploration. 175, 59, 2017.

27. DATTA D.K., GHOSH P.K. Groundwater of the municipalities of southwestern coastal Bangladesh. Surface and Sub-surface Water in Asia: Issues and Perspectives. IOS Press BV, The Netherlands. 120, 2015.

28. NAUS F.L., SCHOT P., AHMED K.M., GRIFFIOEN J. Influence of landscape features on the large variation of shallow groundwater salinity in southwestern Bangladesh. Journal of Hydrology X. 5, 100043, 2019.

29. ZHANG Q., XU P., QIAN H. Assessment of groundwater quality and human health risk (HHR) evaluation of nitrate in the Central-Western Guanzhong Basin, China. International Journal of Environmental Research and Public Health. 16 (21), 4246; DOI: 10.3390/ijerph16214246, 2019.

30. ZAHID A., HOSSAIN A.A., ALI M.H., ISLAM K., ABBASSI S.U. Monitoring the coastal groundwater of Bangladesh. In Groundwater of South Asia 431, Springer, Singapore. 2018.

31. RAHMAN M.A.T.M.T., RAHMAN S.H., MAJUMDER R.K. Groundwater quality for irrigation of deep aquifer in southwestern zone of Bangladesh. Songklanakarin J. Sci. Technol. 34 (3), 345, 2012.

32. SUBRAMANI V., SAXENA K.K. Hydrogeochemistry of groundwater in the Delhi region of India Relation of Groundwater Quantity and Quality. In: Proceedings of the Hamburg Symposium, IAHS Publ (No. 146), August 1983. 1983.

33. SELVAM S., VENKATRAMANAN S., CHUNG S.Y., SINGARAJA C. Identification of groundwater contamination sources in Dindugal district of Tamil Nadu, India using GIS and multivariate statistical analyses. Arabian Journal of Geosciences. 9 (5), 407, 2016.

34. BODRUD-DOZA M., BHUIYAN M.A.H., ISLAM S.M.D., RAHMAN M.S., HAQUE M.M., FATEMA K.J., AHMED N., RAKIB M.A., RAHMAN M.A. Hydrogeochemical investigation of groundwater in Dhaka City of Bangladesh using GIS and multivariate statistical techniques. Groundwater for Sustainable Development. 8, 226, 2019. 
35. BHAT N.A., BHAT A.A., NATH S., SINGH B.P., GUHA D.B. Assessment of Drinking and Irrigation Water Quality of Surface Water Resources of South-West Kashmir, India. Journal of Civil \& Environmental Engineering. 6 (222), 2, 2016.

36. SINGH C.K., RINA K., SINGH R.P., MUKHERJEE S. Geochemical characterization and heavy metal contamination of groundwater in Satluj River Basin. Environmental Earth Sciences. 71 (1), 201, 2013.

37. RINA K., DATTA P.S., SINGH C.K., MUKHERJEE S. Characterization and evaluation of processes governing the groundwater quality in parts of the Sabarmati basin, Gujarat using hydrochemistry integrated with GIS. Hydrological Processes. 26 (10), 1538, 2012.

38. EMENIKE P.C., NNAJI C.C., TENEBE I.T. Assessment of geospatial and hydrochemical interactions of groundwater quality, southwestern Nigeria. Environmental Monitoring Assessment. 190 (440), 2018.

39. AL-FARRAJI A.S., AL-WABEL M.I., EL-SAEID M.H., EL-NAGGAR A.H., AHMED Z. Evaluation of groundwater for arsenic contamination using hydrogeochemical properties and multivariate statistical methods in Saudi Arabia. Journal of Chemistry. 1, 2013.

40. JIANG Y., GUO H., JIA Y., CAO Y., HU C. Principal component analysis and hierarchical cluster analyses of arsenic groundwater geochemistry in the Hetao basin, Inner Mongolia. Geochemistry. 75 (2), 197, 2015.

41. KHELIF S., BOUOUDOUKHA A. Multivariate statistical characterization of groundwater quality in Fesdis, East of Algeria. Journal of Water and Land Development, 37 (1), 65, 2018.

42. CHUNG S.Y., VENKATRAMANAN S., KIM T.H., KIM D.S., Ramkumar T. Influence of hydrogeochemical processes and assessment of suitability for groundwater uses in Busan City, Korea. Environment, Development and Sustainability. 17 (3), 423, 2015.

43. SONKAMBLE S., SAHYA A., MONDAL N.C., HARIKUMAR P. Appraisal and evolution of hydrochemical processes from proximity basalt and granite areas of Deccan Volcanic Province (DVP) in India. Journal of Hydrology. 438, 181, 2012.

44. CHUNG S.Y., VENKATRAMANAN S., KIM T.H., RAMKUMAR T. Influence of hydrogeochemical processes and assessment of suitability for groundwater uses in Busan City, Korea. Environment, Development and Sustainability. 17 (3), 423, 2015.

45. WANG S. Groundwater quality and its suitability for drinking and agricultural use in the Yanqi Basin of Xinjiang Province, Northwest China. Environmental monitoring and assessment. 185 (9), 7469, 2013.

46. PIPER A.M. A graphic procedure in the geochemical interpretation of water-analyses. Eos, Transactions American Geophysical Union. 25 (6), 914, 1944.

47. AHMED A., GHOSH P.K., HASAN M., RAHMAN A. Surface and groundwater quality assessment and identification of hydrochemical characteristics of a southwestern coastal area of Bangladesh. Environmental Monitoring and Assessment. 192, 1, 2020.

48. WHO World Health Organization. Guideline for Drinking Water Quality. 20 Avenue Appia, 1211 Geneva 27, Switzerland. 1984.

49. DoE (Department of Environment). The environment conservation rules 1997. Bangladesh Gazette no. DA-1, Ministry of Environment and Forest, Dhaka, Bangladesh, 1324, 1997 